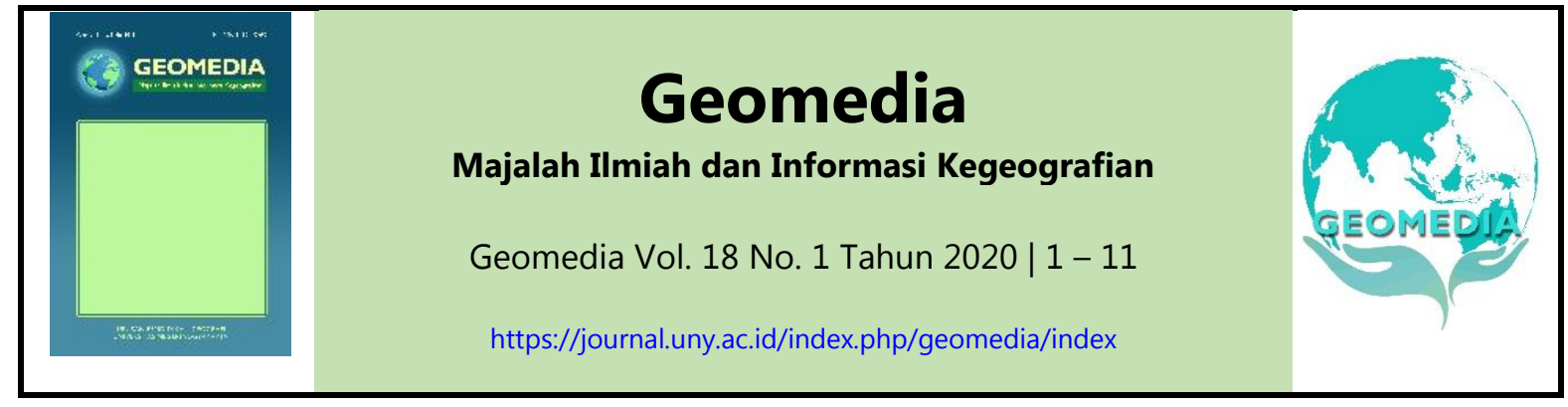

\title{
SEDIMENTASI DI GUMUK PASIR PARANGTRITIS BERDASARKAN TUTUPAN LAHANNYA
}

\section{Sutanto Trijuni Putro ${ }^{a, 1^{*}}$, Sri Haryanti Prasetiyowati ${ }^{b, 2}$}

a Jurusan Pendidikan Geografi, Universitas Negeri Yogyakarta

b Program Studi Teknik Kelautan, Institut Teknologi Yogyakarta

${ }^{1}$ sutanto.tp@uny.ac.id*; ${ }^{2}$ sriharyanti@ity.ac.id

*korespondensi penulis

\begin{tabular}{ll}
\hline Informasi artikel & \\
\hline Sejarah artikel & \\
Diterima & $: 02$ Februari 2020 \\
Revisi & $: 16$ Mei 2020 \\
Dipublikasikan & $: 31$ Mei 2020 \\
\hline
\end{tabular}

A B S T R A K

Gumuk pasir Parangtritis telah mengalami tekanan yang sangat tinggi akibat dari aktivitas manusia, sebagai akibatnya, perkembangan dan fungsi dari gumuk pasir ini berkurang, salah satunya akibat perubahan tutupan lahan yang ada. Faktor yang menyumbang perubahan tutupan lahan yang terbesar adalah wisata, tambak udang dan pertanian. Perubahan tutupan

Kata kunci:

Gumuk pasir

Sedimentasi

Penutup lahan lahan tersebut menyebabkan berkurangnya area gumuk pasir, menghalangi suplai dan transport sedimen.

Kajian dengan seri data panjang mengenai sedimentasi dan perkembangan Gumuk Pasir belum pernah dilakukan, maka dari itu studi ini sebagai pengkayaan data sedimentasi gumuk pasir dan melihat pola spasial sedimentasi pasir saat ini berdasarkan tutupan lahannya. Data yang dikumpulkan adalah data parameter cuaca dan laju perubahan sedimen di lokasi pengamatan selama kurang lebih 2,5 bulan. Data tersebut kemudian diolah untuk menentukan laju sedimentasidan dianalisa secara spasial berdasarkan kondisi lingkungan lokasi pengamatan, khususnya tutupan lahan. Berdasarkan kajian, sedimentasi teraktif terjadi di bagian inti gumuk pasir yang tidak terhalang oleh vegetasi maupun bangunan, dan tepat berada di lorong angin dengan nilai rata-rata maksimum penambahan sebesar 3,5 cm dan pengurangan maksimal 2,5 cm. Sedangkan sedimentasi minim hingga tidak terjadi berada di daerah yang terganggu dan bervegetasi. Hal ini membuktikan bahwa faktor antropogenik telah mempengaruhi kondisi sedimentasi di gumuk pasir menuju ke arah ketidakaktifan sedimentasi.

Keywords:

Sand dune

Sedimentation

Landuse

\section{A B S T R A C T}

Parangtritis sand dune has experienced a lot of preassure from anthropogenic activities, as the result, develompnet and function of the sand dune has decreased, one of the factor was landuse changes. Factors that has the biggest contribution of landuse change was tourism, agricultural practices, and ahrimp aquaculture. Those landuse changes cause the shrinking of sand dune area, prevent the supply and sediment transport.

Long term study of seimentation and sand dune development had never been done before in this area, so as this study was conducted as a sand dune sedimentation data enrichment and to see the spatial pattern of sedimentation based on its landuse. Data collected in this research was data related to weather parameter and sedimentation rate in monitoring stations for 2,5 months. The data then processed in order to find the sedimentation 
rate and spatially analyzed based on each monitoring station environment, especially the landuse. Based on this study, the most active sedimentation located in the core zone with no barrier, vegetation, nor man-made structure, also it was located in wind tunnel with the maximum of average sediment replenishment $3,5 \mathrm{~cm}$ with maximum reduction was $2,5 \mathrm{~cm}$. meanwhile, minimum sedimentation up to no sedimentation was detected in the disturbed and vegetated area. This finding shows that anthropogenic factors has forced the sedimentation to reach to the unactive sedimentation rate.

(C) 2020 (Sutanto Trijuni Putro; Sri Haryanti Prasetiyowati). All Right Reserved

\section{Pendahuluan}

Kajian mengenai gumuk pasir kepesisiran merupakan kajian yang menarik dan masih belum banyak dikaji secara mendalam dan berkala. Indonesia memiliki gumuk pasir yang semakin terdegradasi dan belum banyak kajian yang komprehensif mengenai masalah lingkungan di dalamnya. Salah satu kajian yang masih banyak dikaji adalah sedimentasi dan tutupanlahan di gumuk pasir (Escudero, Silva, \& Mendoza, 2014; Jackson \& Nordstrom, 2011; Mendoza-González, Martínez, Lithgow, Pérez-Maqueo, \& Simonin, 2012; Miyasaka, Okuro, Zhao, \& Takeuchi, 2016; Sigren, Figlus, \& Armitage, 2014; Tsoar, 2008).

Tutupan lahan mempengaruhi sedimentasi di gumuk pasir, dan faktor tersebut merupakan salah satu dampak dari adanya proses antropogenik. Selain itu, gumuk pasir telah mengalami tekanan urbanisasi (Martínez, Maun, \& Psuty, 2008), penambangan pasir (Sridhar \& Bhagya, 2007); (Miththapala, 2008a), konversi lahan menjadi lahan pertanian (Nuraini, Sunarto, \& Santosa, 2016) dan konversi lahan menjadi tambak udang seperti yang terjadi di kepesisiran parangtritis merupakan contoh nyatanya.

Gumuk pasir memiliki peranan dalam ekosistem dan menyediakan jasa lingkungan yang mencakup pelindung infrastruktur dan manusia yang ada di belakangnya (Sudmeier-Rieux \& Masundire, 2006); (Gonsalves \& Mohan, 2011); (Nehren, et al., 2016), mengurangi dampak badai, siklontropis, gelombang, dan banjir pesisir (Gomez-Pina, Juan J. Mufioz-Perez, \& Leyo, 2002); (Dahm et al., 2005); (Thao, Takagi, \& Esteban, 2014); (Nehren, et al., 2016), dan dalam taraf tertentu mengurangi dampak tsunami (Khotimah, 2006; Liu et al., 2005; Miththapala, 2008b). Selain itu, gumuk pasir mampu untuk mengontrol erosi pantai (Barbier, et al., 2011); (Nehren, et al., 2016).
Gumuk pasir memiliki fungsi dalam tataran tertentu untuk mengurangi dampak kenaikan muka laut dan intrusi air laut (Carter, 1991); (Saye \& Pye, 2007); (Heslenfeld, Jungerius, \& Klijn, 2008); (Nehren, et al., 2016).

Berdasarkan hasil dari kajian valuasi ekonomi jasa lingkungan gumuk pasir, nilai pertahun adalah 3,8 milyar, jika dihitung per-hari sebesar 10,4 juta rupiah (Khatimah, Syaukat, \& Ismail, 2018). Perhitungan nilai tersebut mencakup fungsi kawasan gumuk pasir sebagai lokasi wisata, penahan abrasi, sumber pakan ternak, sumber kayu bakar dan penahan angin.

Menurunnya jasa lingkungan secara jangka panjang akan membawa dampak terhadap kehidupan manusia di dalamnya (Daily et al., 1997) dan menurunkan kesejahteraan manusia dalam jeda waktu tertentu (Daily et al., 1997); (RaudseppHearne, et al., 2010). Eksploitasi lingkungan akan menunjukkan dampaknya dalam jangka waktu lama dan menyebabkan kerugian yang jauh lebih tinggi dibandingkan keuntungan ekonomi yang didapat dalam waktu singkat (Daily et al., 1997).

Gumuk Pasir Parangtritis merupakan bentukan yang unik dengan ukuran yang besar (Verstappen, 1957 dalam P. A. Hesp, 2008) dan satu-satunya tempat berkembangnya tipe Barchan (Nuraini et al., 2016) yang langka terbentuk di sistem tropika basah (Sunarto, 2014).

Gumuk Pasir Parangtritis telah mengalami tekanan besar akibat proses antropogenik dan agrogenik (Sunarto, 2014). Perubahan fungsi lahan, penghijauan, wisata (Khatimah et al., 2018; Nuraini et al., 2016) dan pertanian (Nuraini et al., 2016), merupakan contoh tekanan terhadap gumuk pasir yang terjadi. Tekanan lahan yang tinggi ditambah dengan minimnya data sedimen di Gumuk Pasir Parangtritis mendorong dilakukannya kajian ini. Sehingga, diperoleh data 
laju sedimentasi di masing-masing karakteristik tutupan lahan.

Tutupan lahan yang berkembang sekarang adalah vegetasi non-alami gumuk pasir, tambak, pertanian dan lokasi wisata. Bahkan kegiatan tersebut telah merambah ke dalam zona inti gumuk pasir. Perbedaan tutupan lahan dapat dilihat di Gambar 1. Gambar atas mengindikasikan bahwa wilayah kajian masih berupa lahan kosong yang tertutup pasir. Gambar bagian bawah menunjukkan bahwa sebagian besar lokasi telah tertutup oleh vegetasi dan peruntukan lain, dengan menyisakan sebagian kecil lahan kosong.

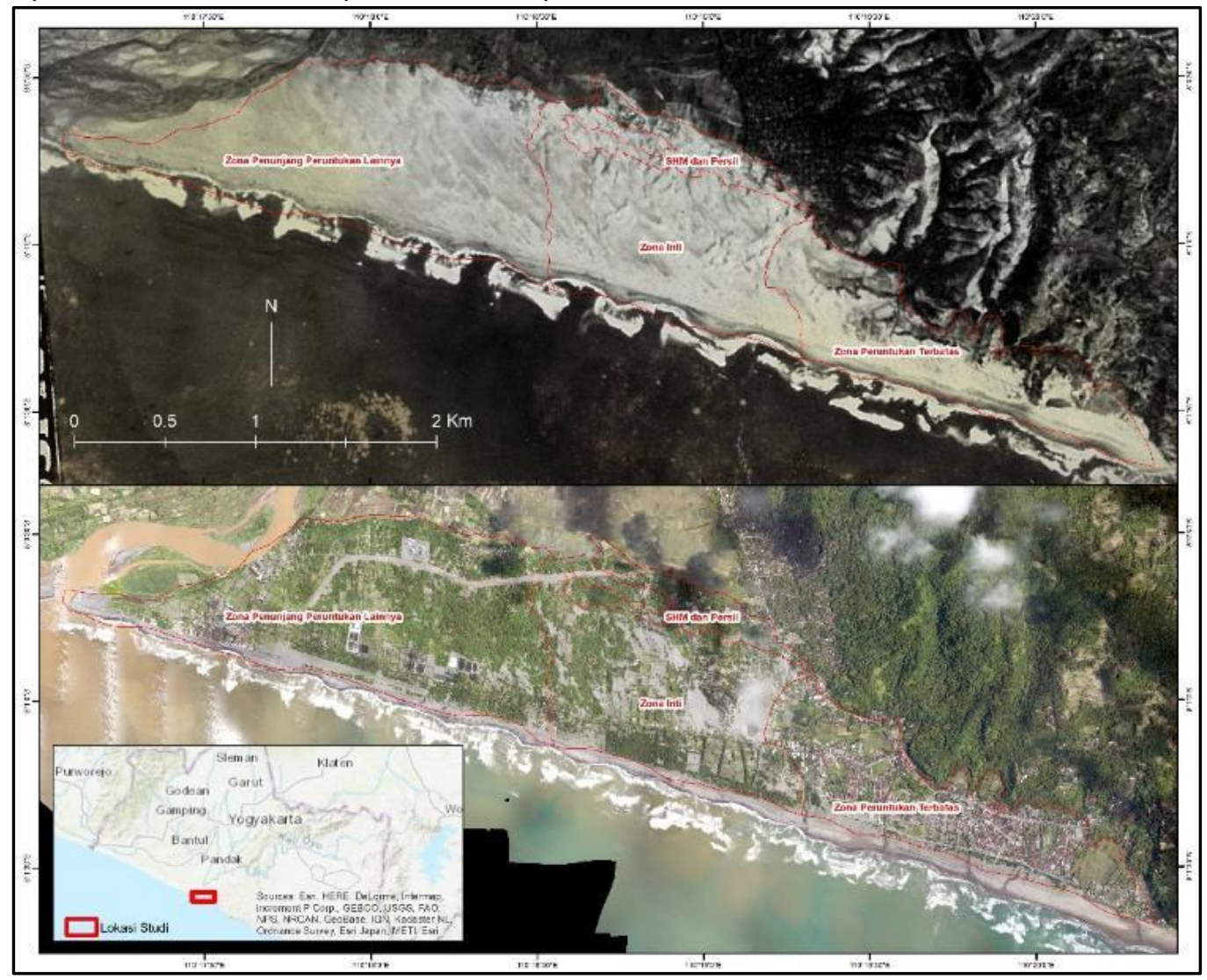

Gambar 1. Foto udara gumuk pasir tahun 1978 (atas) dan 2017 (bawah)

Sumber: Badan Informasi Geospasial

\section{Metode}

Kajian ini menitikberatkan pada pengumpulan dan pengolahan data primer. Data primer diambil secara berkala dalam kurun waktu tiga bulan. Data sedimentasi pasir diambil menggunakan patok ukur kayu dengan penanda ketinggian di salah satu sisinya. Data lain yang dikumpulkan adalah data cuaca tiap stasiun pengamatan. Data cuaca yang dikumpulkan adalah temperatur, kecepatan dan arah angin, kelembaban, serta penyinaran matahari. Parameter-parameter tersebut diukur secara langsung di lapangan menggunakan handheld weather station merek Outest GM 8910 (Gambar 3).

Patok pengamatan dipasang sejumlah 20 buah (Gambar 2) dengan sebaran dan pemilihan lokasi mempertimbangkan tutupan lahan. Indikator lokasi pemasangan patok adalah: lokasi terbuka tanpa halangan dan terhalang. Terhalang dalam artian di sini adalah terhalangnya angin dari arah datangnya karena tutupan vegetasi maupun aktivitas manusia.

Data yang telah terkumpul untuk masingmasing stasiun kemudian diolah untuk mengetahui laju sedimentasi/perubahan ketinggian sedimen untuk kemudian dirata-rata hasilnya. Hasil perubahan sedimentasi kemudian dikomparasikan secara spasial untuk setiap lokasi pengamatan, dengan memperhatikan kondisi lingkungan stasiun pengamatan. 


\section{Hasil dan pembahasan}

20 (Dua puluh) buah stasiun pengamatan telah dipasang dan dimonitor. Deskripsi lokasi pemasangan stasiun pengamatan ditunjukkan di Tabel 1. Secara garis besar, $20 \%$ dari stasiun pengamatan dipasang di titik yang minim penghalang. Sisanya, dipasang di lokasi yang memiliki gangguan.

\section{Sedimentasi}

Berdasarkan pengumpulan data sementara selama 3 (tiga) bulan, diperoleh 7 (tujuh) buah seri data pengamatan (Tabel 2) beserta kendalanya di lapangan. Kendala yang ditemui adalah gangguan yang terjadi pada patok yang dipasang di lapangan. Gangguan yang ditemuiantara lain adalah tercabutnya patok, rusaknya patok (patah, pecah) dan hilangnya patok.

Patok yang hilang berada di stasiun 14 dan 15. Telah diusahakan penggantian patok selama beberapa kali, tetapi selalu hilang. Lokasi patok 14 merupakan lokasi yang biasa digunakan untuk penambangan pasir pantai ilegal (Gambar 4).

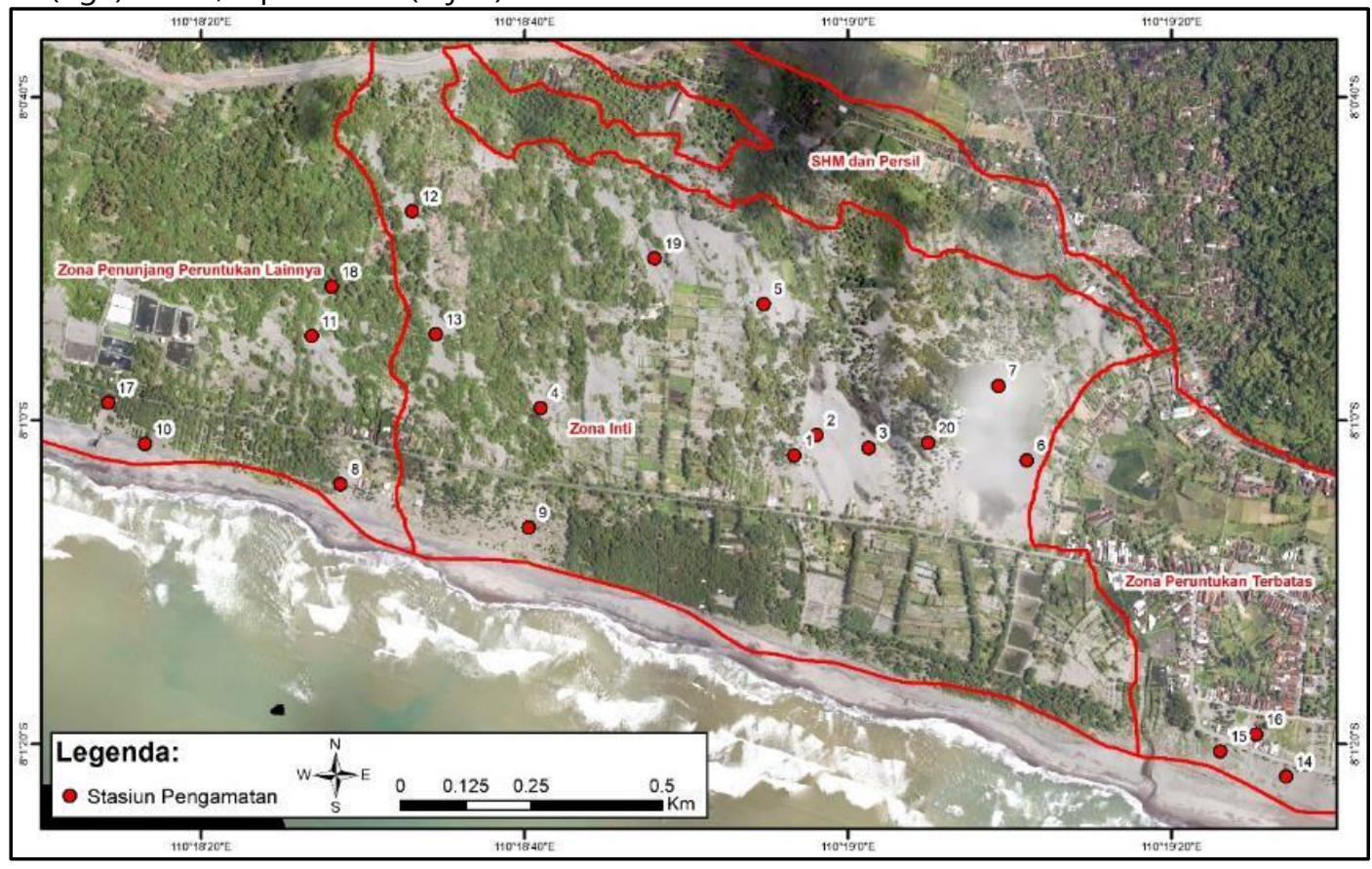

Gambar 2. Lokasi sebaran stasiun pengamatan

Tabel 1. Deskripsi stasiun pengamatan

\begin{tabular}{|c|c|c|c|c|c|}
\hline Stasiun & Zona & Keterangan & Stasiun & Zona & Keterangan \\
\hline 1 & 1 & $\begin{array}{c}\text { Terhalang, Wisata, } \\
\text { vegtasi keras }\end{array}$ & 11 & 3 & Terbuka \\
\hline 2 & 1 & Wisata, terbuka & 12 & 1 & $\begin{array}{c}\text { Terhalang } \\
\text { vegetasi di depan }\end{array}$ \\
\hline 3 & 1 & Wisata, terbuka & 13 & 1 & $\begin{array}{c}\text { Terhalangvegetasi } \\
\text { di depan }\end{array}$ \\
\hline 4 & 1 & Terhalang, semak & 14 & 2 & Terbuka \\
\hline 5 & 1 & Terhalang, semak & 15 & 2 & Terbuka \\
\hline 6 & 1 & Wisata, semak & 16 & 2 & $\begin{array}{c}\text { Dekatwarung, } \\
\text { semak }\end{array}$ \\
\hline 7 & 1 & $\begin{array}{l}\text { Dekat pertanian, } \\
\text { vegetasi keras, } \\
\text { terhalang, seresah }\end{array}$ & 17 & 3 & $\begin{array}{l}\text { Terbuka di depan. } \\
\text { Dilingkupivegetasi }\end{array}$ \\
\hline 8 & 3 & Pertanian, Terbuka & 18 & 3 & Terhalangvegetasi \\
\hline 9 & 1 & Terbuka, semak & 19 & 1 & Terbuka, semak \\
\hline 10 & 3 & Terbuka & 20 & 1 & Terhalang, semak \\
\hline
\end{tabular}

$1=$ Zona Inti $\quad 2=$ Zona Peruntukan Terbatas $3=$ Zona Penunjang Peruntukan Lainnya 


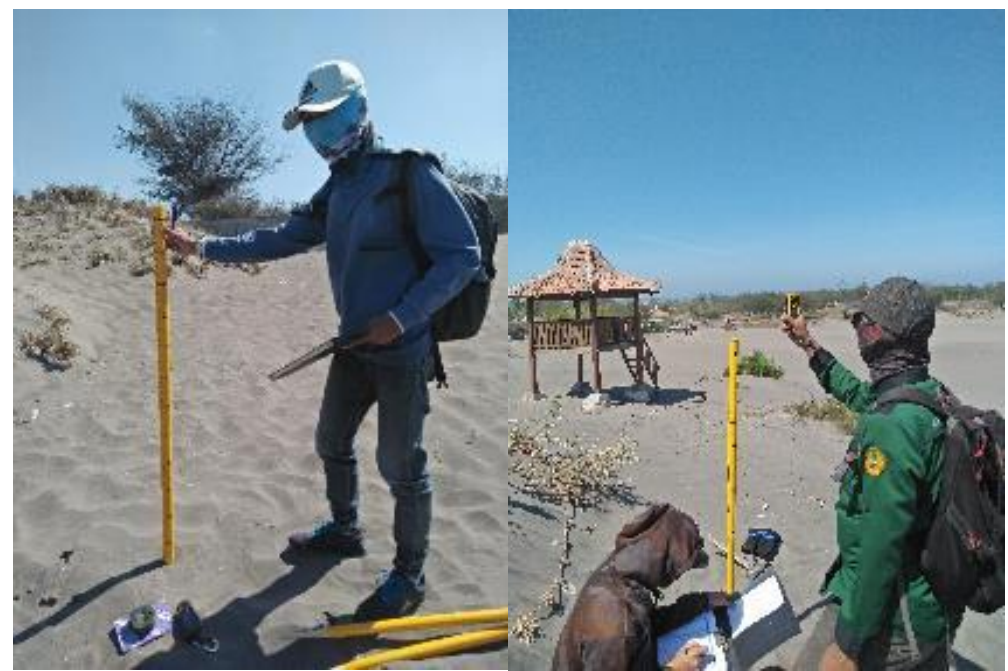

Gambar 3. Pemasangan patok (kiri) dan pengukuran parameter cuaca (kanan)

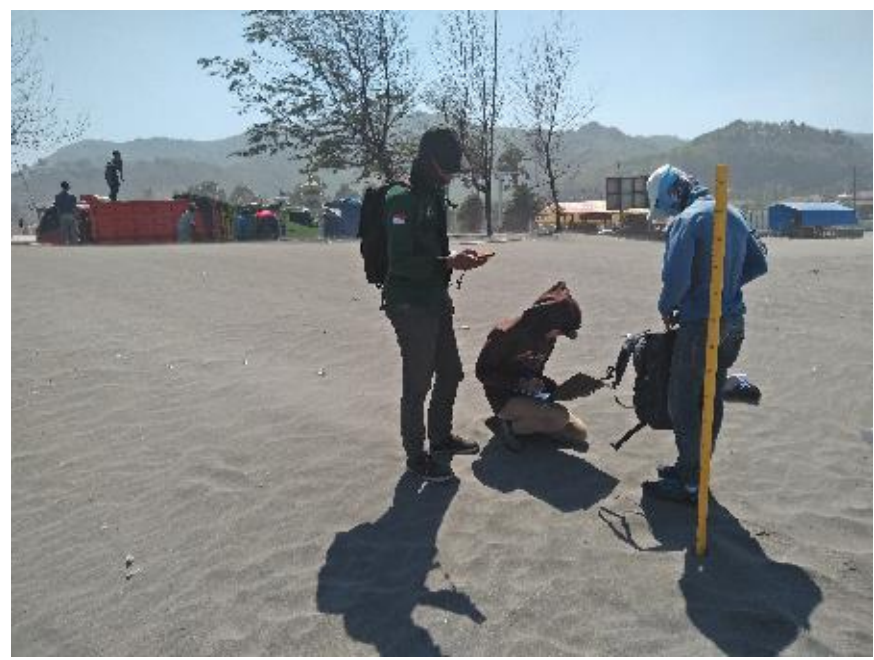

Gambar 4. Lokasi stasiun 14 dan penambangan pasir ilegal (background)

Tabel 2. Hasil PengamatanSedimen (dalam $\mathrm{cm}$ )

\begin{tabular}{|cccccccc|}
\hline Stasiun & $\mathbf{2 4 - 0 7 - 1 8}$ & $\mathbf{2 6 - 0 7 - 1 8}$ & $\mathbf{0 4 - 0 8 - 1 8}$ & $\mathbf{1 1 - 0 8 - 1 8}$ & $\mathbf{2 9 - 0 8 - 1 8}$ & $\mathbf{1 2 - 0 9 - 1 8}$ & $\mathbf{1 6 - 0 9 - 1 8}$ \\
\hline 1 & 31 & 1 & & $-1,5$ & 1,5 & $-0,5$ & $-0,5$ \\
2 & 26 & -10 & -2 & $-0,5$ & $-1,5$ & & 0 \\
3 & 47 & -1 & 0 & 2,5 & $-16,5$ & 2 & -1 \\
4 & 37 & 2,5 & 0,5 & -1 & 1 & 0 & $-0,5$ \\
5 & 63 & 0 & 0 & -1 & 1 & 1 & $-0,5$ \\
6 & 39 & $-0,5$ & $-2,5$ & $-0,5$ & 11 & $-15,5$ & 1 \\
7 & 45 & 0 & 0 & 3 & 0 & $-0,5$ & 0 \\
8 & 60 & -1 & 0 & -1 & -2 & $-0,5$ & $-0,5$ \\
9 & 67 & 0 & 0 & -1 & 0 & 1 & $-0,5$ \\
10 & 50 & -6 & 1 & -1 & 0 & 0,5 & $-0,5$ \\
11 & 53 & $-0,5$ & 1,5 & $-0,5$ & 1 & 0,5 & -1 \\
12 & 53 & -1 & 0 & $-1,5$ & 3,5 & 0 & -1 \\
13 & 50 & -1 & 0 & $-0,5$ & $-1,5$ & 1 & \\
14 & 34 & & & 42 & & & \\
\end{tabular}




\begin{tabular}{|cccccccc|}
\hline \multirow{2}{*}{ Stasiun } & $\mathbf{2 4 - 0 7 - 1 8}$ & $\mathbf{2 6 - 0 7 - 1 8}$ & $\mathbf{0 4 - 0 8 - 1 8}$ & $\begin{array}{c}\text { Tanggal } \\
\mathbf{1 1 - 0 8 - 1 8}\end{array}$ & $\mathbf{2 9 - 0 8 - 1 8}$ & $\mathbf{1 2 - 0 9 - 1 8}$ & $\mathbf{1 6 - 0 9 - 1 8}$ \\
\hline 15 & 63 & 2 & 19 & 42 & & & \\
16 & 30 & 1 & -3 & -3 & -3 & $-0,5$ & $-0,5$ \\
17 & 53 & -2 & $-0,5$ & $-1,5$ & 1 & 1 & $-0,5$ \\
18 & 54 & -2 & 1,5 & $-1,5$ & -2 & 3 & 0 \\
19 & 55 & 2 & 0,5 & -1 & 1,5 & $-0,5$ & -1 \\
20 & 42 & -1 & 2 & 0,5 & 0,5 & 1 & -1 \\
\hline+ & Kotak abu-abu merupakan indikasi ganguan pada alat \\
- & $:$ ketinggian pasir bertambah \\
& ketinggian pasir berkurang
\end{tabular}

Tabel 3. Perubahan ketinggian pasir per stasiun (dalam $\mathrm{cm}$ )

\begin{tabular}{|cccccc|}
\hline Stasiun & + & - & Stasiun & + & - \\
\hline 1 & 1,25 & 0,83 & 11 & 0,75 & 0,67 \\
2 & 0,00 & 1,25 & 12 & 3,50 & 1,17 \\
3 & 2,25 & 1,00 & 13 & 1,00 & 1,00 \\
4 & 1,33 & 0,75 & 14 & 0,00 & 0,00 \\
5 & 1,00 & 0,75 & 15 & 0,00 & 0,00 \\
6 & 1,00 & 1,17 & 16 & 1,00 & 2,00 \\
7 & 0,00 & 0,50 & 17 & 1,00 & 1,13 \\
8 & 0,00 & 1,00 & 18 & 2,25 & 1,83 \\
9 & 1,00 & 0,75 & 19 & 1,33 & 0,75 \\
10 & 0,75 & 2,50 & 20 & 1,00 & 1,00 \\
\hline
\end{tabular}

Sumber: Perhitungan tahun 2018

Hasil yang diperoleh memberikan gambaran secara umum bahwa terdapat pola sedimentasi yang terjadi. Pola tersebut dikontrol oleh kondisi faktor yang berbeda untuk tiap titik pengamatan. Identifikasi hasil lebih lanjut menunjukkan bahwa factor tutupan lahan memberikan pengaruh yang berbeda terhadap proses sedimentasi yang terjadi. Kondisi serupa diamati melalui satelit di Iran, menunjukkan bahwa pola sedimentasi berbeda bergantung dari tutupan lahannya (Rezaei, Sameni, Fallah Shamsi, \& Bartholomeus, 2016). Penelitian lain mengemukakan bahwa tutupan lahan di gumuk pasir mempengaruhi erosi dan efek gelombang (Karanci, Kurum, \& Overton, 2014).

Pengolahan data untuk erosi (tanda -) dan sedimentasi (tanda + ) di Tabel 3 menunjukkan bahwa potensi terjadinya sedimentasi dan erosi berbeda untuk tiap titik pengamatan. Kondisi tersebut utamanya dikontrol oleh tutupan lahan dan vegetasi (Hesp, 2002); dan ada tidaknya penghalang angin di depan titik pengamatan.
Selain itu, tutupan vegetasi juga mempengaruhi morfologi dari bentukan yang terjadi (Hesp, 2009).

\section{Pengontrol Sedimentasi}

Berdasarkan hasil perhitungan hasil perubahan endapan pasir tiap stasiun (Tabel 3), diketahui bahwa lajus edimentasi dan erosi berbeda untuk tiap titik. Laju sedimentasi terbesar berada di titik nomor 12 sebesar $3,5 \mathrm{~cm}$. sedangkan sedimentasi terkecil berada di titik 7 (Gambar 6). Erosi terbesar berada di titik 10 sebesar 2,5 cm dan terkecil di titik 7 sebesar 0,5 $\mathrm{cm}$.

Titik 12 (Gambar 5) merupakan bagian dari zona inti. Titik ini di lingkupi oleh vegetasi berupa akasia di keempat sisinya, walaupun demikian, angin masih leluasa untuk bergerak. Terdapat gelembur gelombang dengan interval yang saling berdekatan. Jarak antar gelembur gelombang 3 sampai dengan $5 \mathrm{~cm}$. Interval tersebut mengindikasikan bahwa area ini minim erosi (Nuraini et al., 2016). 


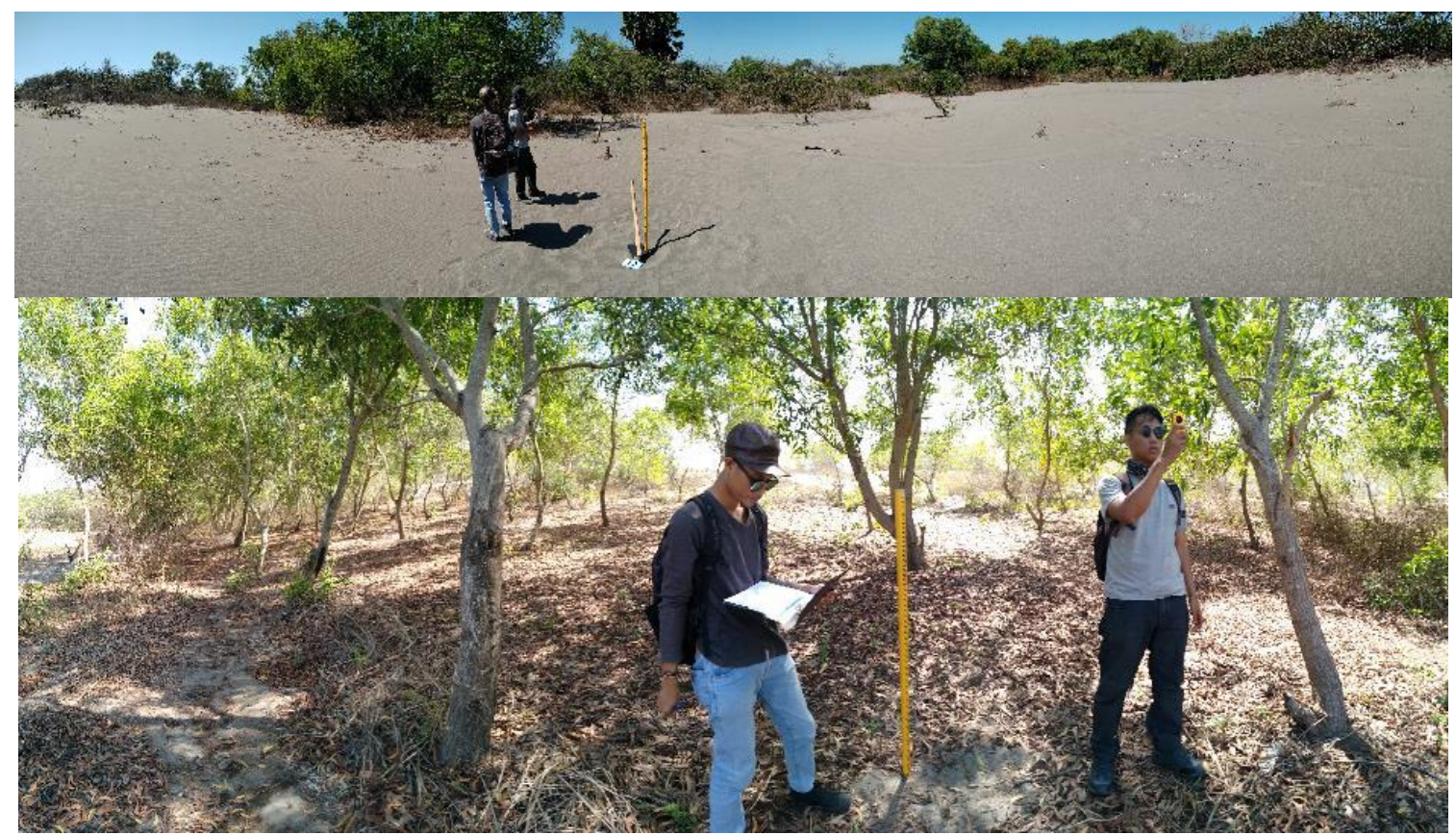

Gambar 5. Lokasi stasiun no. 12 (atas) dan no. 7 (bawah)

Titik nomor 7 (Gambar 5), merupakan kawasan zona inti yang telah banyak dipengaruhi aktivitas manusia. Titik no 7 dipenuhi oleh tanamanakasia dan permukaan tanah tertutup oleh seresah daun akasia. Tidak dijumpai angin yang secara signifikan mampu mengangkat pasir di titik ini. Bagian selatan titik ini merupakan bukit pasir dengan tinggi hingga \pm 10 meter. Bagian utara dari bukit ini adalah bagian datar yang oleh warga diubah menjadi lahan pertanian.

Titik 7 memiliki permukaan bergelombang yang tadinya merupakan bagian dari gumuk pasir aktif. Dilihat dari catatan lapangan, nilai sedimentasi rata-rata adalah nol, artinya, tidak terjadi pengendapan pasir dikarenekan angin yang mencapai titik ini terhalang oleh vegetasi yang ada.

Titik-titik dengan pengendapan lebih dari 2 $\mathrm{cm}$ selain titik 12 adalah titik 18 dan 3 . Titik 18 berada di tengah-tengah kumpulan akasia, dengan lokasi titik memiliki indikasi gangguan manusia dimana banyak dijumpai jejak kaki, sehingga tidak dijumpai adanya gelembur gelombang. Bahkan pernah dijumpai adanya sekelompok orang yang berkemah di sekitar lokasi dan melakukan gangguan terhadap patok pengukuran. Kecepatan angin rata-rata di lokasi ini sangat rendah dibandingkan titik lainnya. Berdasarkan fakta lapangan, kemungkinan tingginya pengendapan dan erosi merupakan akibat dari gangguan manusia. Perlu pengamatan lebih jauh mengenai hal ini.

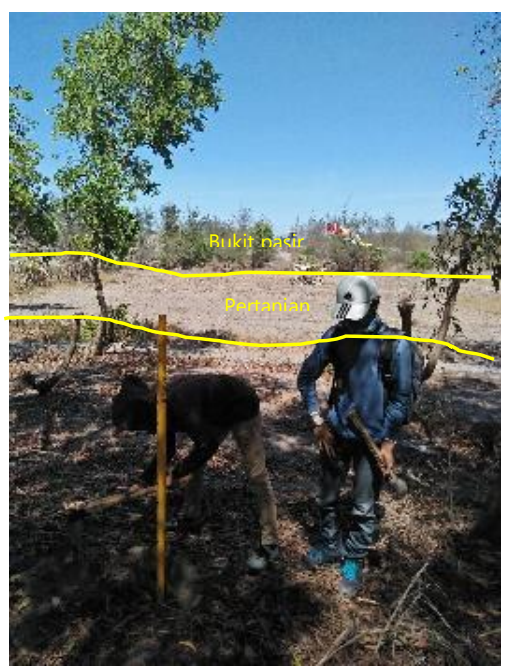

Gambar 6. Lokasi titik 7

Titik 3 (Gambar 7) merupakan titik yang juga berada di zona inti, sama seperti titik 12. Titik no. 3 berada di area wisata, tanpa halangan vegetasi, dan memiliki bentukan gumuk pasir yang cukup baik, dibuktikan salah satunya dengan banyaknya gelembur gelombang dengan interval yang rapat hingga sedang, sebagai indikasi adanya erosi. Erosi yang terjadi rata-rata sebesar 1 $\mathrm{cm}$ selama pengukuran. 


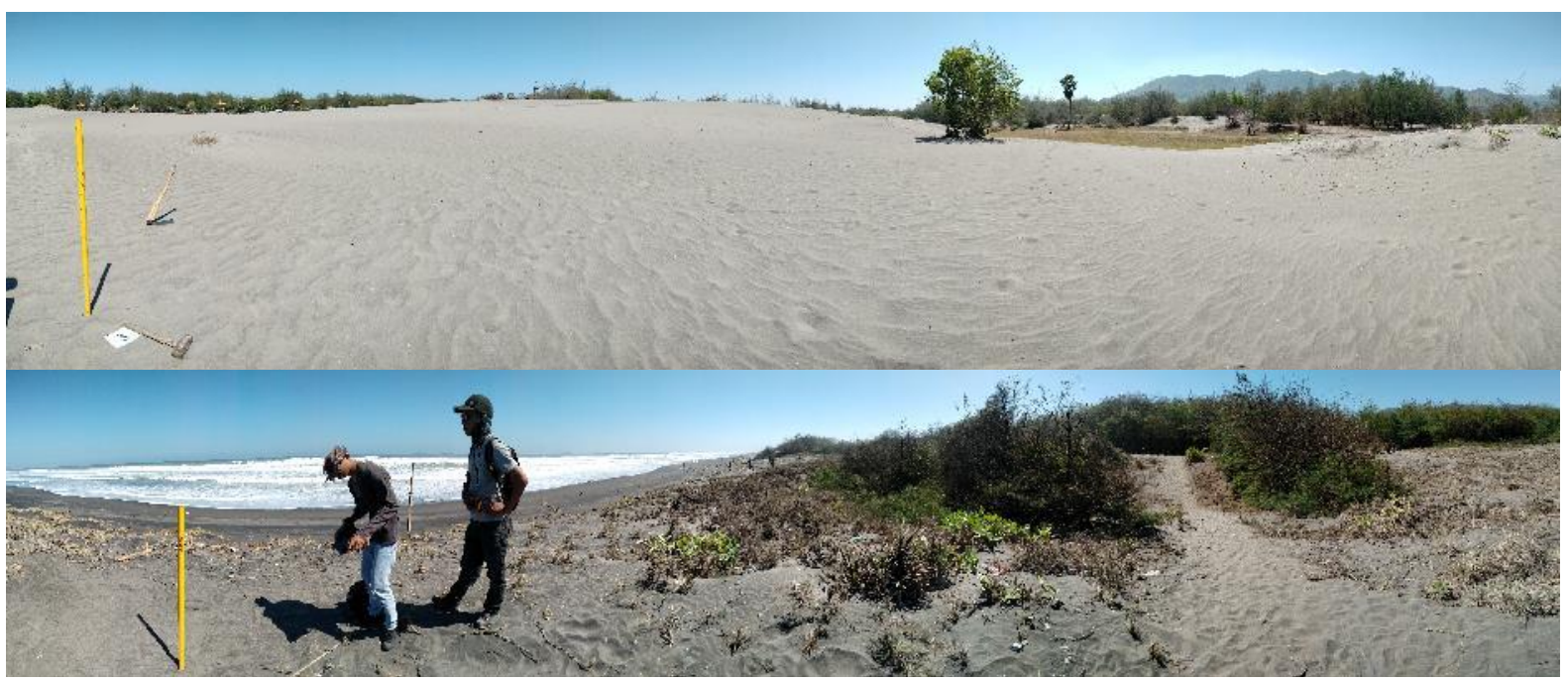

Gambar 7. Titik 3 (atas) dan titik 10 (bawah)

Titik yang mengalami erosi tertinggi adalah titik no 10 (Gambar 7), berada dekat dengan pantai dengan lokasi berada di belakang punggungan yang terbentuk akibat pasang surut dan gelombang. Erosi yang terjadi di titik ini diakibatkan oleh tingginya kecepatan angin yang terjadi, bahkan menjadi lokasi di mana angin memiliki kecepatan paling tinggi. Faktor lain adalah sangat terbukanya titik ini dengan tanpa penghalang di depannya yang menyebabkan hembusan angin mampu membawa material.

Titik berikutnya dengan tingkat erosi tinggi adalah titik 16 (Gambar 8). Titik ini berada dekat dengan pantai, berada di sebelah belakang warung dan penitipan motor, tetapi memiliki muka yang terbuka, sehingga angin dapat dengan mudah melewati titik ini tanpa penghalang.

Absennya penghalang di depan titik 16 dan adanya rumah di bagian depan menyebabkan turbulensi sehingga tingkat erosi menjadi tinggi. Selain itu di titik ini bentukan gundukan pasir cenderung memanjang mengikuti arah angin. Kecepatan angin di titik ini cukup tinggi, walaupun tidak setinggi yang ada di titik 10 . Semakin tinggi kecepatan angin, maka semakin tinggi pula laju transport pasir oleh angin (Liu, et al., 2011).

Selama dilakukan pengukuran, diketahui bahwa lokasi dengan tutupan vegetasi maupun penghalang, akan cenderung memiliki tingkat sedimentasi dan erosi yang tidak tinggi. Hal ini dipengaruhi oleh adanya penghalang yang menyebabkan angin tidak mampu membawa materi dan kehilangan energinya. Sedangkan lokasi-lokasi dengan laju erosi tinggi, merupakan titik-titik dengan daerah terbuka di mana angin dapat membawa material dengan leluasa tanpa adanya penghalang.

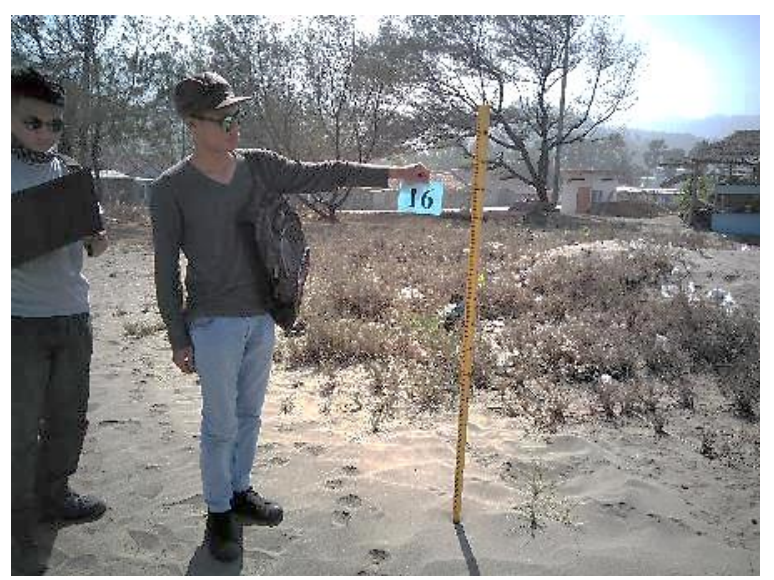

Gambar 8. Lokasi titik 16

Contoh titik-titik yang berpenghalang dengan lajusedimentasi dan erosi rendah adalahtitik 1, 4, 5, 13, 19 dan 20. Jika dikalkulasikan antara erosi dan sedimentasi, maka diketahui titik mana yang mengalami surplus sedimen dan titik mana yang defisit. Titik-titik yang mengalami surplus sedimen adalah titik 1, 4, 5, 9, 11, 12, 18 dan 19. Sedangkan titik deficit sedimen adalah 2 , $6,7,8,10,13,16$ dan 17. Kondisi surplus maupun deficit ditentukan dari kondisi tutupan lahan yang ada. Kondisi tutupan lahan juga mempengaruhi pergerakan angin lokal yang ada di suatu wilayah. Titik-titik yang mengalami surplus dipengaruhi oleh hambatan angin oleh vegetasi, sehingga pasir berhenti di titik tersebut. Sesuai dengan kajian 
terdahulu bahwa vegetasi mempengaruhi dinamika di gumukpasir (Khotimah, 2006) bahkan mengurangi perpindahan sedimen (Goldsmith, 1985). Sedangkan titik dengan kondisi defisit, disebabkan oleh karena terbukanya lokasi terhadap arah datangnya angin yang mengakibatkan lebih ekstensifnya erosi yang terjadi.

\section{Simpulan}

Sedimentasi di Gumuk Pasir Parangtritis dipengaruhi oleh tutupan lahannya. Secara umum, tutupan lahan tersebut akan berpengaruh terhadap pergerakan angin lokal yang mampu mengakibatkan terjadinya erosi maupun sedimentasi pasir. Daerah dengan tutupan terbuka dan memiliki pergerakan angin yang tidak terhalang, cenderung memiliki tingkat erosi lebih tinggi dibandingkan dengan lokasi dengan tutupan lahan bervegetasi maupun terprengaruh oleh tingginya aktivitas manusia. Lokasi yang demikian cenderung mengalami sedimentasi dan erosi lebih tinggi karena terbukanya lahan. Dampak dari aktifitas manusia di gumuk pasir menyebabkan sedimentasi pasir ke arah minimum (sedimentasi tidak aktif).

\section{Ucapan Terima kasih}

Terimakasih kami ucapkan kepada Kementerian Riset, Teknologi, dan Pendidikan Tinggi yang telah membiayai penelitian ini melalui skema penelitian dosen pemula tahun 2018 melalui kontrak No.109/SP2H/LT/DRPM/2018. Terimakasih pula kami ucapkankepada LPPM Institut Teknologi Yogyakarta yang mendukung terselesaikannya kegiatan ini. Terimakasih pula kepada Pihak Prangtritis Geomaritime Science Park yang telah memberikan citra temporal dan data iklim untuk pelaksanaan penelitian ini. Tak lupa terimakasih kami ucapkan kepada mahasiswa yang membantu pengumpulan data di penelitian ini.

\section{Referensi}

Barbier, E. B., Hacker, S. D., Kennedy, C., Koch, E. W., Stier, A. C., \& Silliman, B. R. (2011). The Value of Estuarine and Coastal Ecosystem Services. Ecological Monographs, 81(2), 169 193.

Carter, R. (1991). Near-Future Sea Level Impacts on
Coastal Dune Landscapes. Landscape Ecology, 6(1-2), 29-39.

Dahm, J., Dahm, J., Jenks, G., Jenks, G., Bergin, D., \& Bergin, D. (2005). Community-based Dune Management for the Mitigation of Coastal Hazards and Climate Change Effects: A Guide for Local Authorities, 36.

Daily, G. C., Alexander, S., Ehrlich, P. R., Goulder, L., Lubchenco, J., Matson, P. A., ... Woodwell, G. M. (1997). I ssues in Ecology. Issues in Ecology, 4(4), 1-12. https://doi.org/10928987

Escudero, M., Silva, R., \& Mendoza, E. (2014). Beach Erosion Driven by Natural and Human Activity at Isla del Carmen Barrier Island, Mexico. Journal of Coastal Research, 71(1994), 62-74. https://doi.org/10.2112/SI71-008.1

Goldsmith, V. (1985). Coastal Dunes. In R. A. Davis (Ed.), Coastal Sedimentary Environments. Second Revised Extended Revision (pp. 303378). New York: Springer Verlag New York. https://doi.org/10.1007/978-1-4684-00564_5

Gomez-Pina, G., Juan J. Mufioz-Perez, J. L., \& Leyo, C. (2002). Sand dune management problems and techniques, Spain. Journal of Coastal Research(36), 325-332.

Gonsalves, J., \& Mohan, P. (Eds.). (2011). Strengthening resilience in post-disaster situations: Stories, Experience and Lessons from South Asia. Canadian Electronic Library. New Delhi: Academic Foundation. Retrieved from

http://search.ebscohost.com/login.aspx?dire $\mathrm{ct}=$ true $\&$ scope $=$ site $\& \mathrm{db}=$ nlebk $\& \mathrm{db}=$ nlabk \&AN $=489923$

Heslenfeld, P., Jungerius, P., \& Klijn, J. (2008). European Coastal Dunes: Ecological Values, Threats, Opportunities and Policy Development. In M. Caldwell, G.Heldmaier, R. Jackson, O. Lange, H.A.Mooney, E.-D. Schulze, K. U. Sommer, M. L.Martínez, \& N. P. Psuty (Eds.), Ecological Studies,Vol. 171. Analysis and Synthesis (pp. 335-351). Berlin/Heidelberg: Springer.

Hesp, P. (2002). Foredunes and blowouts: initiation, geomorphology and dynamics. Geomorphology, 48, 245-268. https://doi.org/10.1016/S0169555X(02)00184-8

Hesp, P. A. (2008). Coastal Dunes in the Tropics 
and Temperate Regions: Location , Formation, Morphology and Vegetation Processes. In M. L. Martínez \& N. P. Psuty (Eds.), Coastal Dunes, Ecology and Coservation (Vol. 171, pp. 29-49). Berlin: Springer. https://doi.org/10.1007/978-3540-74002-5

Hesp, P. (2009). Coastal Dunes in the Tropics and Temperate Regions: Location, Formation,Morphology and Vegetation Processes. In M. Caldwell, G.Heldmaier, R. Jackson, O. Lange, H.A.Mooney, E.-D. Schulze, U. Sommer, M. L.Martínez, \& N. P. Psuty (Eds.), Coastal Dunes, Ecology and Conservation. Volume 171. Analysis and Synthesis (pp. 29-49). Berlin Heidelberg New York: Springer.

Jackson, N. L., \& Nordstrom, K. F. (2011). Aeolian sediment transport and landforms in managed coastal systems: A review. Aeolian Research, 3(2), 181-196 https://doi.org/10.1016/j.aeolia.2011.03.011

Karanci, A., Kurum, M. O., \& Overton, M. F. (2014). Land Cover Effect on Dune Erosion and Overwash. Coastal Engineering Proceedings, 34,

1-8. https:/doi.org/https://doi.org/10.9753/icce.v 34.sediment.53

Khatimah, K. (2017). Analisis Ekonomi Gumuk Pasir di Desa Parangtritis, Kabupaten Bantul, Propinsi Yogyakarta. Bogor: Sekolah Pascasarjana Institut Pertanian Bogor. Retrieved November 07, 2018,

Khatimah, K., Syaukat, Y., \& Ismail, A. (2018). Analisis Penilaian Ekonomi Gumuk Pasir Parangtritis di Kecamatan Kretek, Kabupaten Bantul , DIY. Jurnal Ekonomi Dan Pembangunan Indonesia, 17(2), 138-150. https://doi.org/http://dx.doi.org/10.21002/j epi.v17i2.666 Analisis

Khotimah, N. (2006). Kelestarian Gumuk Pasir Pantai Parangtritis Sebagai Penghalang (Barrier) Alami Gelombang Pasang dan Tsunami. Geomedia, 4(2), 81-92. https://doi.org/10.21831/gm.v4i2.19008

Liu, P. L., Lynett, P., Fernando, H., Jaffe, B. E., Fritz, H., Higman, B., ... Synolakis, C. (2005). Observation by the International Tsunami Survey Team in Sri Lanka. Science, 308(June), 1595. https://doi.org/10.1193/1.2205897

Liu, L., Shi, P., X. H., Liu, T., Guo, L., Zhang, X., . . . Xiong, Y. (2011). Natural Factors Influencing
Blown Sand Hazards in Beijing. International Journal of Disaster Risk Science, 2(2), 23-31.

Martínez, M., Maun, M., \& Psuty, N. (2008). The Fragility and Conservation of the World's Coastal Dunes: Geomorphological, Ecological, and Socioeconomic Perspectives. In M. Caldwell, G.Heldmaier, R. Jackson, O. Lange, H.A.Mooney, E.-D. Schulze, K. U. Sommer, M. L.Martínez, \& N. P. Psuty (Eds.), Ecological Studies, Vol. 171. Analysis and Synthesis (pp. 355-369). Berlin/Heidelberg: Sprimger.

Mendoza-González, G., Martínez, M. L., Lithgow, D., Pérez-Maqueo, O., \& Simonin, P. (2012). Land use change and its effects on the value of ecosystem services along the coast of the Gulf of Mexico. Ecological Economics, 82, 2332.

https://doi.org/10.1016/j.ecolecon.2012.07.0 18

Miththapala, S. (2008a). Seagrasses and Sand Dunes (Vol. 3). IUCN. Retrieved from https://portals.iucn.org/library/sites/library/f iles/documents/CES-003.pdf

Miththapala, S. (2008b). Seagrasses and Sand Dunes (Vol. 3).

Miyasaka, T., Okuro, T., Zhao, X., \& Takeuchi, K. (2016). Classification of Land Use on SandDune Topography by Object-Based Analysis, Digital Photogrammetry, and GIS Analysis in the Horqin Sandy Land, China. Environments, 3(4),17.https://doi.org/10.3390/environment s3030017

Nehren, U., Thai, H. H., Marfai, M. A., Raedig, C., Alfonso, S., Sartohadi, J., \& Castro, C. (2016). Ecosystem Services of Coastal Dune Systems for Hazard Mitigation: Case Studies from Vietnam, Indonesia, and Chile. In F. G. Renaud, K. Sudmeier-Rieux, M. Estrella, U. Nehren, \& U. Nehren (Ed.), Ecosystem-Based Disaster Risk Reduction and Adaptation in Practice. Switzerland: Springer International Publishing.

Nuraini, F., Sunarto, \& Santosa, L. W. (2016). Pengaruh vegetasi terhadap dinamika perkembangan gumuk pasir di Pesisir Parangkusumo. Geomedia, 14(2), 1-11.

Raudsepp-Hearne, C., Peterson, G. D., Tengö, M., Bennett, E. M., Holland, T., Benessaiah, K., ... Pfeifer, L. (2010). Untangling the Environmentalist's Paradox: Why Is Human Well-being Increasing as Ecosystem Services 
Degrade? BioScience, 60(8), 576-589.

Rezaei, M., Sameni, A., Fallah Shamsi, S. R., \& Bartholomeus, H. (2016). Remote sensing of land use/cover changes and its effect on wind erosion potential in southern Iran. Peerl, 4, e1948. https://doi.org/10.7717/peerj.1948

Saye, S. E., \& Pye, K. (2007). Implications of sea level rise for coastal dune habitat conservation in Wales, UK. Journal of Coastal Conservation, 11(1), 31-52. https://doi.org/10.1007/s11852-007-0004-5

Sigren, J. M., Figlus, J., \& Armitage, A. R. (2014). Coastal sand dunes and dune vegetation: Restoration, erosion, and storm protection. Shore \& Beach, 82(4), 5-12. Retrieved from https://login.proxy.lib.duke.edu/login?url=ht tps://search.proquest.com/docview/167339 6322? accountid=10598\%0Ahttp://pm6mt7v g3j.search.serialssolutions.com?ctx_ver=Z39. 88-2004\&ctx_enc=info:ofi/enc:UTF8\&rfr_id=info:sid/ProQ\%3Aasfaocean\&rft_v al_fmt=info:ofi/

Sridhar, K. R., \& Bhagya, B. (2007). Coastal sand dune vegetation: A potential source of food, fodder and pharmaceuticals. Livestock
Research for Rural Development, 19(6), 1-10. Retrieved from http://www.Irrd.org/Irrd19/6/srid19084.htm Sudmeier-Rieux, K., \& Masundire, H. (2006). Ecosystems, Livelihoods and Disasters: An integrated approach to disaster risk management. (A. R. Rietbergen, Ed.) Switzerland and Cambridge: IUCN.

Sunarto. (2014). Geomorfologi dan Kontribusinya dalam Pelestarian Pesisir Bergumuk Pasir Aeolian dari ancaman bencana Agrogenik dan Urbanogenik. Yogyakarta: Universitas Gadjah Mada.

Thao, N. D., Takagi, H., \& Esteban, M. (2014). Coastal Disasters and Climate Change in Vietnam Engineering and Planning Perspectives. London: Elsevier.

Tsoar, H. (2008). Land Use and its Effect on the Mobilization and Stabilization of the NorthWestern Negev Sand Dunes. In S. Breckle, A. Yair, \& M. Veste (Eds.), Arid Dune Ecosystems. Ecological Studies (Analysis and Synthesis) (pp. 79-89). Berlin, Heidelberg: Springer Berlin Heidelberg. https://doi.org/10.1007/978-3-540-754985_6 